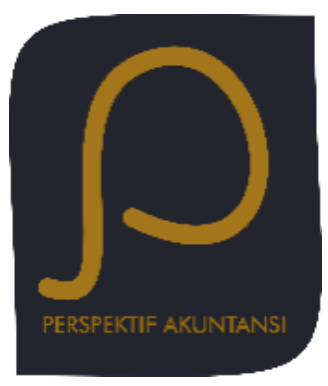

Perspektif Akuntansi

Volume 4 Nomor 1 (Februari 2021), hal. 13-33

ISSN: 2623-0194 (Print), 2623-0186 (Online)

Copyright(C) The Authors(s). All Rights Reserved

Center for Accounting Development and Research (CARD)

Fakultas Ekonomika dan Bisnis,

Universitas Kristen Satya Wacana

DOI: https://doi.org/10.24246/persi.vXiX.p13-33

http://ejournal.uksw.edu/persi

\title{
Pengaruh Kualitas Sistem dan Informasi Dalam Pendidikan Akuntansi
}

\author{
Aditya Pradina Hermawan ${ }^{1}$ \\ Aprina Nugrahesthy Sulistya Hapsari \\ Program Studi Akuntansi Universitas Kristen Satya Wacana
}

Received Abstract. This research aims to examine the effect of system 13/04/2021 quality, information quality, user satisfaction, and the net

Revised

$19 / 04 / 2021$ benefits of using information systems in accounting learning.

Accepted 20/04/2021

Data in this research were obtained by distributing questionnaires with a sample of 70 students Accounting Study Program. This research is a descriptive quantitative study and uses multiple linear regression analysis. The results showed that system quality and information quality had a positive effect on user satisfaction, and information quality and user satisfaction had a positive effect on net benefits, but system quality did not affect net benefits. The results of this study can be used as consideration in making improvements related to the implementation and use of the FLearn in accounting learning and education.

Keywords: e-learning, accounting education, system quality, information quality, net benefits

\footnotetext{
1 232017054@student.uksw.edu
} 


\begin{abstract}
Abstrak. Penelitian ini bertujuan untuk menguji pengaruh mengenai kualitas sistem, kualitas informasi, kepuasan pengguna serta manfaat bersih dari penggunaan sistem informasi pada pembelajaran akuntansi. Data dalam penelitian ini diperoleh melalui penyebaran kuesioner dengan sampel mahasiswa Program Studi Akuntansi sebanyak 70 responden. Penelitian ini merupakan penelitian dengan kuantitatif deskriptif dan menggunakan analisis regresi linier berganda. Hasil penelitian menunjukkan kualitas sistem dan kualitas informasi berpengaruh positif terhadap kepuasan pengguna, serta kualitas informasi dan kepuasan pengguna berpengaruh positif terhadap manfaat bersih, namun kualitas sistem tidak berpengaruh terhadap manfaat bersih. Hasil dari penelitian ini dapat digunakan sebagai bahan pertimbangan dalam melakukan perbaikan terkait dengan penerapan dan penggunaan FLearn pada pembelajaran dan pendidikan akuntansi.
\end{abstract}

Kata kunci: e-learning, pendidikan akuntansi, kualitas sistem, kualitas informasi, manfaat bersih

\title{
Pendahuluan
}

Berbagai isu mengenai kasus pendidikan sedang menjadi topik hangat di media massa hingga saat ini, salah satunya yaitu mengenai kualitas pendidikan yang ada di Indonesia. Menurut hasil survei Programme for International Student Assessment (PISA) pada tahun 2018 menempatkan Indonesia pada posisi 74 dari 79 negara terkait dengan kualitas pendidikan (Organisation for Economic Co-operation and Development, 2018). Hal tersebut pun menjadi bahan evaluasi bagi pemerintah dan institusi sektor pendidikan di Indonesia untuk memperbaiki kualitas pembelajaran pada pendidikan yang ada. Perbaikan kualitas pembelajaran pada pendidikan tersebut dapat dilakukan dengan berbagai cara, salah satunya yaitu dengan memanfaatkan perkembangan teknologi. Selain itu, pada awal tahun 2020 telah terjadi kasus pandemi Corona Virus Disease 2019 (COVID-19) yang melanda hampir di segala penjuru dunia termasuk Indonesia. Kasus pandemi ini diperkirakan mulai masuk dan menyebar di Indonesia pada tanggal 2 Maret 2020 yaitu dengan adanya kasus dua pasien positif COVID-19 yang dikonfirmasi langsung oleh pemerintah (Pranita, 2020). Masuknya COVID-19 ke Indonesia menyebabkan kelumpuhan pada berbagai jenis sektor yang ada seperti ekonomi, perdagangan, pariwisata, transportasi, hingga sektor pendidikan. 
Pada sektor pendidikan, pemerintah bertindak cepat untuk mencegah persebaran COVID-19 yaitu melalui Kementerian Pendidikan dan Kebudayaan (KEMENDIKBUD) dengan mengeluarkan surat edaran yang berisi kebijakan jika kegiatan belajar mengajar melalui tatap muka secara langsung akan ditiadakan dan digantikan dengan pembelajaran online atau pembelajaran melalui daring (Fithra, 2020). Berdasarkan surat edaran tersebut, institusi dan lembaga pendidikan di Indonesia mulai melakukan proses kegiatan belajar mengajar secara online dan menggunakan sistem informasi sebagai media untuk melakukan kegiatan pembelajaran. Berbagai macam sistem informasi yang dapat digunakan dalam kegiatan belajar mengajar yaitu seperti zoom, whatsapp, skype, google meet, google classroom, e-mail, blogs, web based dan berbagai macam sistem informasi lainnya.

Sistem informasi yang memiliki kualitas sistem dan informasi yang memadai serta memberikan manfaat tentunya akan lebih diminati untuk digunakan terlebih lagi dalam penggunaanya untuk proses kegiatan belajar mengajar. Beberapa penelitian mengenai penggunaan sistem informasi seperti Chopra, Madan, Jaisingh, dan Bhaskar (2019) serta Jaiyeoba dan Iloanya (2019) pada penggunaan sistem informasi di elearning yang menunjukkan jika kualitas sistem dan kualitas informasi yang dihasilkan dari sistem informasi e-learning berkontribusi terhadap penggunaan dari sistem informasi tersebut, sehingga semakin bermanfaat dan mudah untuk dioperasikan sistem informasi tersebut maka akan semakin diminati untuk digunakan oleh user. Hasil serupa dari Rui-Hsin dan Lin (2018) juga menyatakan jika penggunaan sistem informasi pada pendidikan dan pelatihan di kepolisian menunjukkan jika sistem informasi akan lebih diminati jika dirasa mampu memberikan manfaat dan mudah untuk digunakan. Andoh (2018), Bakhsh, Mahmood, dan Sangi (2017) juga menyatakan jika kemudahan penggunaan dan kebermanfaatan pada sistem informasi pada mobile learning menjadi faktor penentu seseorang menggunakan sistem informasi tersebut.

Penggunaan sistem informasi sebagai media untuk pembelajaran telah banyak diterapkan di berbagai macam bidang studi, tak terkecuali pada pendidikan akuntansi. Penerapan sistem informasi pada bidang akuntansi khususnya dalam pendidikan akuntansi tentunya juga harus didukung dengan kualitas sistem dan informasi yang baik. Beberapa penelitian mengenai pengaruh kualitas sistem dan kualitas informasi di bidang akuntansi telah banyak dilakukan seperti Buana dan Wirawati (2018) menyatakan jika kualitas sistem dan kualitas informasi yang ada pada sistem informasi PDAM berpengaruh signifikan terhadap kepuasan dan penggunaan sistem informasi. Hasil serupa juga ditunjukkan oleh Rukmiyati dan Budiartha (2016) jika kualitas sistem dan kualitas informasi pada software akuntansi yang diterapkan di hotel berbintang menunjukkan jika kedua faktor tersebut berpengaruh positif terhadap kepuasan dan penggunaan dari sistem informasi. Krisdiantoro, Subekti, dan Prihatiningtias (2018) juga menyatakan jika kualitas 
sistem dan kualitas informasi yang dihasilkan berpengaruh terhadap penggunaan sistem informasi pada sistem pengadaan barang langsung (SIMPeL).

Pada pendidikan akuntansi, kualitas sistem dan informasi yang baik akan semakin mendukung kegunaan dari sistem informasi tersebut sebagai media untuk pembelajaran khususnya untuk pendidikan akuntansi sehingga mudah untuk dioperasikan dan dapat memberikan output berupa informasi yang berkualitas. Informasi yang berkualitas merupakan informasi yang tepat waktu, akurat serta relevan sehingga informasi yang diterima tersebut mampu membantu dalam proses pengambilan keputusan serta dapat memberikan manfaat bagi penggunanya sehingga dapat menjadi media pembelajaran yang efektif khususnya pada pendidikan akuntansi. Selain itu, melalui penggunaan sistem informasi yang berkualitas pada pendidikan akuntansi tentunya akan mendukung pembelajaran akuntansi yang semakin baik sehingga nantinya akan menghasilkan lulusan yang berkualitas.

Berbeda dari penelitian sebelumnya, penelitian ini dilakukan untuk menguji pengaruh mengenai kualitas sistem, kualitas informasi, kepuasan pengguna dan manfaat bersih dari penggunaan sistem informasi terlebih lagi dilakukan pada institusi pendidikan khususnya pendidikan akuntansi dan dilakukan pada saat terjadinya kasus pandemi COVID-19 yang menyebabkan seluruh kegiatan pembelajaran akuntansi dilakukan secara online. Objek penelitian ini yaitu portal Flexible Learning (FLearn) yang digunakan sebagai salah satu media untuk pembelajaran akuntansi oleh Program Studi (Prodi) Akuntansi, Fakultas Ekonomika dan Bisnis (FEB) di Universitas Kristen Satya Wacana (UKSW). FLearn merupakan sebuah portal pembelajaran elektronik yang dimiliki oleh UKSW dan digunakan sebagai salah satu media dalam kegiatan pembelajaran di UKSW.

Program studi akuntansi FEB UKSW dipilih sebagai objek penelitian karena telah menerapkan sistem informasi sebagai salah satu sarana pembelajaran online serta semua modul mengenai pembelajaran akuntansi telah tersedia dan dapat diakses melalui portal FLearn. Selain itu, Prodi Akuntansi FEB UKSW dipilih karena pada visi dari fakultas yaitu menjadi fakultas yang terkemuka di kawasan ASEAN pada tahun 2022 sehingga seharusnya pendidikan di FEB khususnya pada Prodi Akuntansi telah menggunakan sistem informasi yang berkualitas dalam melakukan kegiatan pembelajaran. Alasan lain dipilihnya Prodi Akuntansi FEB UKSW karena merupakan salah satu institusi pendidikan yang juga terdampak karena adanya COVID-19 sehingga seluruh kegiatan pembelajaran khususnya di bidang akuntansi dilakukan secara online atau menggunakan media daring salah satunya melalui penggunaan portal FLearn.

Melalui penelitian ini diharapkan dapat memberikan manfaat bagi berbagai pihak, pertama bagi civitas akademika diharapkan dapat memberikan kontribusi yaitu informasi mengenai efektivitas penggunaan sistem informasi khususnya dalam pendidikan akuntansi. Kedua, bagi akademisi diharapkan dapat menambah literatur 
mengenai penggunaan sistem informasi di bidang akuntansi khususnya pada pendidikan akuntansi, sedangkan bagi objek penelitian yaitu Prodi Akuntansi FEB UKSW dapat digunakan menjadi bahan pertimbangan untuk mengevaluasi dari penggunaan portal FLearn sebagai media yang digunakan untuk pembelajaran akuntansi mampu memberikan dampak yang positif atau tidak.

\section{Telaah Pustaka}

\section{Teori Technology Acceptance Model (TAM)}

Technology Acceptance Model atau TAM adalah teori yang dapat digunakan untuk menjelaskan mengenai alas an penggunaan sistem informasi oleh seorang pengguna (user) serta faktor-faktor yang mempengaruhi penerimaan dari sistem informasi tersebut (Davis, 1989). Pada teori ini menjelaskan jika terdapat dua faktor utama yang mempengaruhi seseorang dalam menggunakan suatu sistem informasi. Dua faktor tersebut adalah persepsi kemudahan penggunaan (perceived ease of use) dan persepsi kebermanfaatan (perceived usefulness) yang akan menjadi dasar dari sikap penggunaan sistem informasi oleh seorang user (attitude toward using). Sikap penggunaan sistem informasi oleh user tersebut selanjutnya akan berpengaruh terhadap niat perilakunya dalam penggunaan sistem informasi tersebut (behavioral intention to use) dan hingga akhirnya akan berpengaruh dan menentukan perilaku penggunaan sistem informasi yang sebenarnya oleh user tersebut (actual system use). Pada teori ini juga terdapat variabel eksternal yang dapat mempengaruhi penggunaan dari sistem informasi tersebut seperti keamanan, pelatihan, pemahaman, dan lain sebagainya.

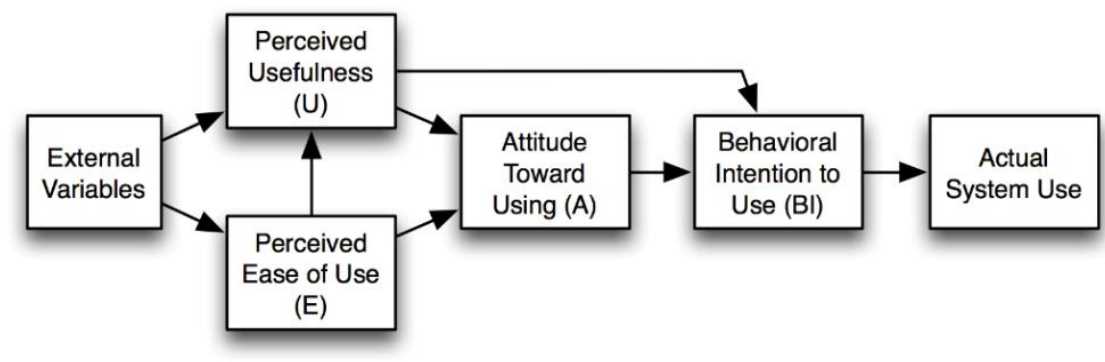

Sumber: Davis (1989)

\section{Gambar 1. Teori Technology Acceptance Model}

Persepsi kemudahan penggunaan merupakan seberapa besar sistem informasi tersebut mudah untuk digunakan dan dipahami oleh user. Sedangkan persepsi kebermanfaatan merupakan seberapa besar manfaat yang diperoleh dalam menggunakan sistem informasi tersebut. Venkatesh dan Davis (2000) berpendapat jika teori TAM merupakan teori yang dianggap paling baik dan cocok untuk digunakan dalam menjelaskan mengenai penerimaan dan perilaku user terhadap suatu sistem informasi. Pada penelitian terdahulu telah banyak yang menggunakan 
dan menerapkan teori ini seperti Rukmiyati dan Budiartha (2016) dan Sayekti dan Putarta (2016) yang menerapkan teori TAM pada software akuntansi. Penelitian ini menggunakan teori TAM karena dapat digunakan untuk menjelaskan mengenai kemudahan dan kebermanfaatan dari penggunaan sistem informasi FLearn sebagai salah satu media pembelajaran dan pendidikan akuntansi di FEB UKSW.

\section{DeLone \& McLean IS Success Model}

Merupakan sebuah model kesuksesan sistem informasi dari DeLone dan McLean (1992) yang digunakan untuk mengukur keberhasilan dari penerapan suatu sistem informasi. Pada model ini terdapat beberapa komponen yang digunakan sebagai pengukur kesuksesan suatu sistem informasi yaitu kualitas informasi, kualitas sistem, kepuasan pengguna, penggunaan, dampak individual dan dampak organisasional.

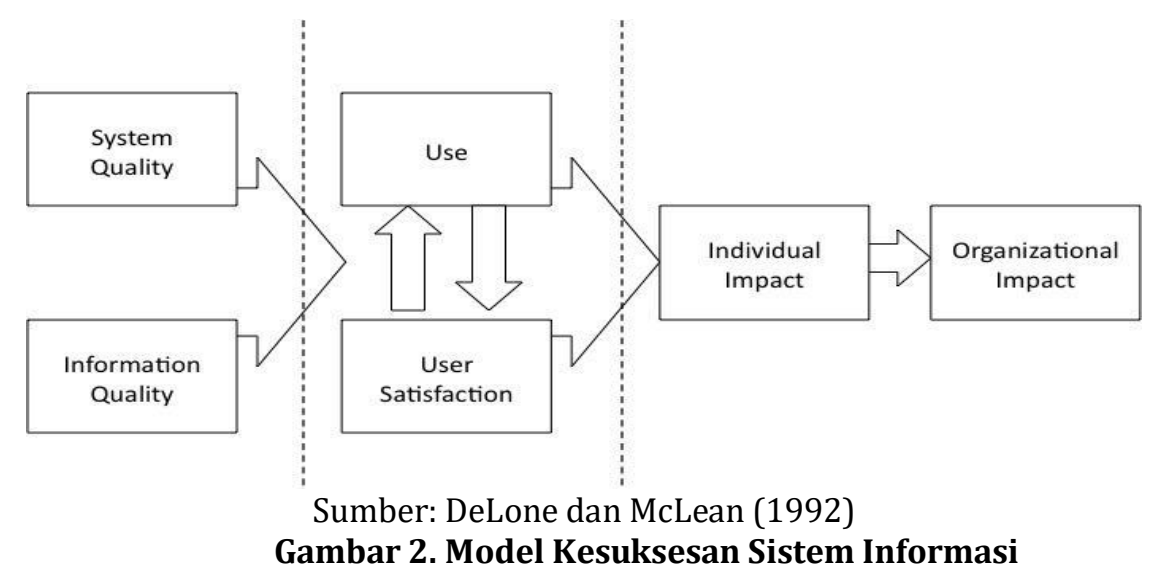

Pada model ini, kualitas sistem (system quality) dan kualitas informasi (information quality) menjadi dua faktor penting yang mempengaruhi penggunaan (use) dan kepuasan pengguna (user satisfaction) dari penggunaan sistem informasi. Penggunaan (use) sistem informasi dapat mempengaruhi kepuasan penggunaan (user satisfaction) baik secara positif maupun negatif. Penggunaan (use) dan kepuasan penggunaan (user satisfaction) akan berpengaruh terhadap dampak individual (individual impact) dan selanjutnya akan berpengaruh terhadap dampak organisasional (organizational impact).

Kualitas sistem (system quality) merupakan karakteristik dari sistem informasi yang digunakan seperti kemudahan penggunaan, kemudahan mempelajari, kemudahan akses, dan lain sebagainya. Sedangkan, kualitas informasi (information quality) merupakan karakteristik dari output atau informasi yang dihasilkan seperti tepat waktu, jelas, konsisten, relevan, dan lain sebagainya. Banyak penelitian yang telah menggunakan model kesuksesan sistem informasi ini seperti Krisdiantoro et al. (2018), Buana dan Wirawati (2018) dan Widodo, Handayani, dan Saifi (2013) yang menerapkan model ini pada penelitian sistem informasi akuntansi dan manajemen. Penelitian ini menggunakan model kesuksesan sistem informasi dari DeLone dan McLean (1992) karena dapat digunakan untuk menjelaskan mengenai kualitas sistem 
informasi dan kualitas informasi dari penggunaan FLearn yang digunakan sebagai salah satu media pembelajaran online di bidang akuntansi.

\section{Pendidikan Akuntansi}

Menurut Effendi (2013) akuntansi adalah sebuah proses mengidentifikasi, mengukur, mencatat, menggolongkan dan mengikhtisarkan serta melaporkan informasi keuangan dengan menggunakan ukuran moneter yang ditujukan untuk para stakeholder dalam pengambilan keputusan. Sedangkan menurut Kieso, Weygandt, dan Warfield (2016) akuntansi merupakan kegiatan mengidentifikasi, mencatat dan mengkomunikasikan peristiwa ekonomi pada suatu perusahaan atau organisasi kepada pihak yang memiliki kepentingan. Menurut Kartikahadi (2016) akuntansi merupakan sistem informasi keuangan yang memiliki tujuan untuk menghasilkan dan memberikan laporan yang relevan kepada pihak yang memiliki kepentingan. Sedangkan akuntansi menurut Warren (2014) merupakan sistem informasi yang menyajikan laporan untuk para stakeholder mengenai kondisi perusahaan dan aktivitas ekonominya. Dalam dunia pendidikan, akuntansi merupakan salah satu mata pelajaran yang juga diajarkan seperti di tingkat Sekolah Menengah Atas atau Kejuruan (SMA/SMK) ataupun di tingkat perguruan tinggi. Seiring dengan perkembangan teknologi, saat ini kegiatan pembelajaran dan pendidikan akuntansi dapat dilakukan dengan memanfaatkan berbagai media salah satunya dengan menggunakan sistem informasi.

\section{Pengembangan Hipotesis}

Kualitas sistem mencangkup tingkat kecepatan akses sistem, tingkat kecepatan waktu respon, dan tingkat kecepatan pengiriman dokumen (DeLone \& McLean, 1992). Penggunaan sistem informasi dapat dikatakan bermanfaat jika mampu membantu dan dapat memberikan dampak yang positif bagi penggunanya antara lain seperti kemudahan pengoperasian, membantu dalam memenuhi kebutuhan, membantu dalam menyelesaikan pekerjaan dan lain sebagainya. Mengenai hubungan antara kualitas sistem dengan manfaat bersih adalah semakin mudah dan cepat suatu sistem maka akan semakin berguna dan bermanfaat untuk digunakan dalam membantu menyelesaikan pekerjaan. Krisdiantoro et al. (2018) memperoleh hasil jika kualitas sistem akan berpengaruh terhadap manfaat bersih, sistem informasi yang memiliki kualitas sistem dan kualitas data yang baik akan memberikan keuntungan bersih terhadap para stakeholder.

$\boldsymbol{H}_{1}$ : Kualitas Sistem berpengaruh positif terhadap manfaat bersih

Efektivitas merupakan suatu keberhasilan yang diperoleh dari penggunaan sistem informasi. Keberhasilan penerapan suatu sistem informasi antara lain dapat diukur melalui kualitas sistem, manfaat sistem dan tingkat kepuasan pengguna. Kepuasan merupakan evaluasi keseluruhan dari pengalaman dalam menggunakan sistem informasi dan memiliki dampak potensial dari penggunaan sistem informasi tersebut 
(Dekeng \& Rahmawati, 2015). Kepuasan user dalam menggunakan sistem informasi merupakan tingkat kepuasan terhadap sistem informasi yang digunakan dan output yang dihasilkan dari sistem informasi tersebut (Saleh \& Darwanis, 2012). Semakin baik kualitas sistem informasi tentunya akan memiliki dampak yang besar terhadap manfaat yang diperoleh user dalam menggunakan sistem informasi sehingga dapat mempengaruhi tingkat kepuasan dari penggunaan sistem tersebut. Penelitian yang telah dilakukan oleh Buana dan Wirawati (2018) dan Rukmiyati dan Budiartha (2016) juga menunjukkan jika kualitas sistem informasi berpengaruh terhadap kepuasan user.

$\boldsymbol{H}_{2}$ : Kualitas Sistem berpengaruh positif terhadap kepuasan pengguna

Kualitas informasi merupakan sebuah ukuran dari informasi yang dihasilkan dari suatu sistem informasi dapat bermanfaat dan membantu penggunanya dalam menyelesaikan tugas atau pekerjaan. Kualitas informasi yang dimaksud yaitu kualitas dari keluaran atau output yang dihasilkan dari sistem informasi. Dekeng dan Rahmawati (2015) dalam penelitiannya menyatakan jika kualitas informasi adalah kualitas dari output yaitu berupa informasi yang dihasilkan dari penggunaan sistem informasi tersebut. Semakin baik kualitas informasi yang dihasilkan maka akan semakin baik dan tepat pula keputusan yang akan diambil sehingga manfaat yang diterima juga akan besar. Penelitian dari Krisdiantoro et al. (2018) menghasilkan jika kualitas informasi yang terdapat dalam sistem informasi berpengaruh terhadap manfaat bersih dari penggunaan sistem informasi. Semakin berkualitas informasi yang dihasilkan dari sistem informasi tentunya akan semakin memberikan dampak yang signifikan bagi para pengguna atau stakeholder.

$\boldsymbol{H}_{3}$ : Kualitas informasi berpengaruh positif terhadap manfaat bersih.

Semakin baik kualitas output atau informasi yang dihasilkan tentunya akan semakin memberikan manfaat terhadap user dalam mengambil keputusan. Ketika sistem informasi yang digunakan dirasa dapat memberikan manfaat maka akan muncul rasa kepuasan dalam penggunaanya. Hasil dari penelitian yang pernah dilakukan oleh Rukmiyati dan Budiartha (2016) menyatakan jika kualitas informasi berpengaruh terhadap kepuasan user. Penelitian dari Nurhayati, Fauziahdan, dan Halimatusadiah (2016) dan Supriatna (2012) juga menyatakan jika kualitas informasi yang dihasilkan dari penggunaan sistem informasi berpengaruh terhadap tingkat kepuasan user dalam menggunakan sistem informasi.

$\boldsymbol{H}_{4}$ : Kualitas informasi berpengaruh positif terhadap kepuasan pengguna

Oktavia (2016) menjelaskan jika sistem informasi yang berkualitas dapat memberikan kepuasan bagi penggunanya. Ketika pengguna menganggap jika sistem informasi tersebut penting dalam meningkatkan kinerjanya baik secara individu ataupun organisasi maka akan muncul rasa puas dalam penggunaannya. Kepuasan dapat berpengaruh terhadap kinerja individu dan kinerja individu tersebut akan 
berpengaruh terhadap kinerja organisasi. Kepuasan dari penggunaan sistem informasi tersebut dapat memberikan dampak yang positif terhadap penggunaannya baik secara individu ataupun kelompok dalam mencapai tujuannya. Penelitian yang dilakukan oleh Ikhyanuddin (2017) memperoleh hasil jika kepuasan pengguna berpengaruh terhadap manfaat bersih yang dihasilkan.

$\boldsymbol{H}_{5}$ : Kepuasan pengguna berpengaruh positif terhadap manfaat bersih

\section{Metoda}

\section{Jenis dan Sumber Data}

Penelitian ini menggunakan metode penelitian kuantitatif deskriptif, dalam penelitian ini terdapat tiga variabel bebas dan dua variabel terikat. Variabel bebas dalam penelitian ini terdiri dari kualitas sistem dan kualitas informasi, dan kepuasan pengguna, sedangkan untuk variabel terikat dalam penelitian ini adalah kepuasan pengguna dan manfaat bersih dari penggunaan sistem informasi. Data yang digunakan dalam penelitian ini adalah data primer yang diperoleh langsung melalui pengisian kuesioner oleh responden. Kuesioner dikirimkan kepada responden melalui google form. Kuesioner yang dibagikan merupakan jenis kuesioner campuran yang di dalamnya responden memberikan jawaban berupa scoring dan jawaban terbuka.

\section{Populasi dan Sampel}

Penelitian ini mengambil populasi mahasiswa S1 Akuntansi Universitas Kristen Satya Wacana (UKSW) yang aktif pada tahun ajaran 2020/2021. Sedangkan sampel yang digunakan yaitu diambil dengan cara memilih sampel secara acak (probability sampling) pada mahasiswa S1 Akuntansi UKSW angkatan 2017, 2018 dan 2019 yang aktif pada tahun ajaran 2020/2021 dan hingga akhir yang dapat dikumpulkan yaitu sebanyak 70 jawaban responden. 


\section{Tabel 1. Variabel, Definisi Operasional dan Indikator Empiris}

\begin{tabular}{|c|c|c|}
\hline Variabel & Definisi Operasional Variabel & Indikator Empiris \\
\hline Kualitas Sistem & $\begin{array}{l}\text { Kualitas sistem merupakan keterkaitan } \\
\text { antar fitur dalam sistem termasuk } \\
\text { kinerja dari sistem tersebut } \\
\text { mencangkup tingkat kecepatan akses, } \\
\text { tingkat kecepatan waktu respon, dan } \\
\text { tingkat kecepatan pengiriman dokumen } \\
\text { (DeLone \& McLean, 1992). }\end{array}$ & $\begin{array}{l}\text { Navigation } \\
\text { Searchability } \\
\text { Structure } \\
\text { Usability } \\
\text { Functionality } \\
\text { Accessibility } \\
\text { (Urbach, N., Smolnik \& } \\
\text { Riempp, 2010) }\end{array}$ \\
\hline Kualitas & Kualitas informasi merupakan kualitas & Usefulness \\
\hline Informasi & $\begin{array}{l}\text { dari hasil output sistem informasi } \\
\text { (Dekeng \& Rahmawati, 2015). }\end{array}$ & $\begin{array}{l}\text { Understandability } \\
\text { Interestingness } \\
\text { Reliability } \\
\text { Completeness } \\
\text { Timeliness } \\
\text { (Urbach, N., Smolnik \& } \\
\text { Riempp, 2010) }\end{array}$ \\
\hline $\begin{array}{l}\text { Kepuasan } \\
\text { Pengguna }\end{array}$ & $\begin{array}{l}\text { Kepuasan pengguna merujuk pada } \\
\text { sejauh mana pengguna menganggap } \\
\text { sistem tersebut berguna dan adanya } \\
\text { keinginan untuk menggunakannya lagi } \\
\text { (Xinli, 2015). }\end{array}$ & $\begin{array}{l}\text { Kecukupan } \\
\text { Efisiensi } \\
\text { Efektivitas } \\
\text { Kepuasan keseluruhan } \\
\text { (Urbach, N., Smolnik \& } \\
\text { Riempp, 2010) }\end{array}$ \\
\hline Manfaat Bersih & $\begin{array}{l}\text { Manfaat bersih merupakan manfaat } \\
\text { yang dapat dirasakan oleh pengguna } \\
\text { sistem informasi, manfaat dapat dilihat } \\
\text { dari tingkat penggunaan sistem } \\
\text { informasi dan adanya kepuasan yang } \\
\text { muncul terhadap penggunaan sistem } \\
\text { informasi karena memberikan nilai } \\
\text { tambah bagi pengguna (Krisdiantoro et } \\
\text { al., 2018). }\end{array}$ & $\begin{array}{l}\text { Memberikan manfaat bagi } \\
\text { pengguna } \\
\text { Meningkatkan produktivitas } \\
\text { pengguna } \\
\text { Meningkatkan kinerja } \\
\text { pengguna } \\
\text { (Krisdiantoro et al., 2018) } \\
\text { dan (Wahyuni, 2011) }\end{array}$ \\
\hline
\end{tabular}

\section{Teknik Analisis Data}

Data penelitian ini diperoleh dengan cara membagikan kuesioner melalui e-mail, kemudian data yang telah diperoleh akan diolah terlebih dahulu dengan melakukan pengujian instrumen yaitu uji validitas dan uji reliabilitas. Uji validitas dilakukan untuk menguji tingkat validitas pada sebuah instrumen, sedangkan uji reliabilitas dilakukan untuk menguji tingkat konsistensi dari jawaban responden. Langkah selanjutnya yaitu melakukan uji asumsi klasik terhadap data yang diperoleh antara lain melakukan uji normalitas, uji multikolinieritas, uji heteroskedastisitas dan uji linearitas. Teknik analisis data yang digunakan dalam penelitian ini adalah analisis linier berganda karena didalam penelitian ini terdapat tiga variabel bebas. Pada penelitian ini terdapat dua model persamaan yang digunakan terkait dengan analisis regresi linier berganda, yaitu: 
Pengujian Model $1 \mathrm{KP}=\alpha 0 \mathrm{i}+\beta 1 \mathrm{KS}+\beta 2 \mathrm{KI}+\varepsilon$

Keterangan:
KP: Kepuasan Pengguna
KI: Kualitas Informasi
KS: Kualitas Sistem
ع: Error Term

\section{Pengujian Model $2 \mathrm{MB}=\alpha 0 \mathrm{i}+\beta 1 \mathrm{KS}+\beta 2 \mathrm{KI}+\beta 3 \mathrm{KP}+\varepsilon$}

Keterangan:

MB: Manfaat Bersih

KP: Kepuasan Pengguna

KS: Kualitas Sistem

$\varepsilon:$ Error Term

KI: Kualitas Informasi

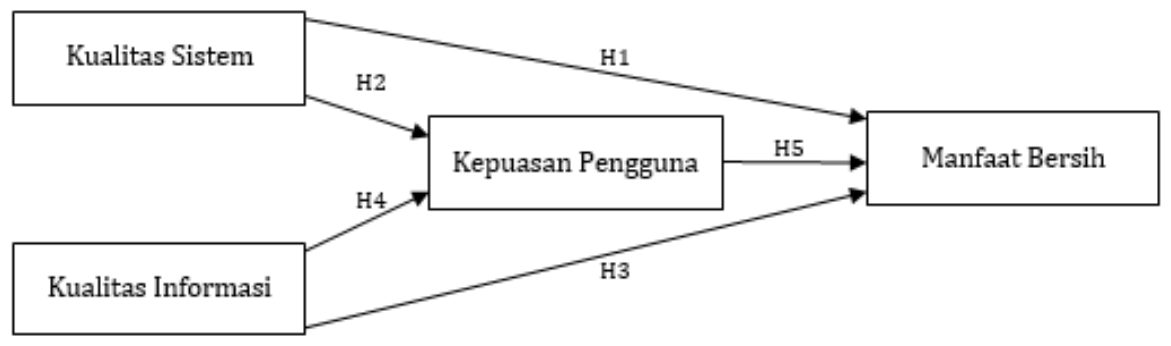

Gambar 3. Model Penelitian

\section{Hasil dan Pembahasan}

\section{Hasil}

Hasil statistik penelitian setelah data yang diperoleh diolah adalah sebagai berikut:

\section{Tabel 2. Statistik Deskriptif}

\begin{tabular}{cccccc}
\hline Variabel & N & $\begin{array}{c}\text { Nilai } \\
\text { Terendah }\end{array}$ & $\begin{array}{c}\text { Nilai } \\
\text { Tertinggi }\end{array}$ & $\begin{array}{c}\text { Nilai Rata- } \\
\text { Rata }\end{array}$ & $\begin{array}{c}\text { Simpangan } \\
\text { Baku }\end{array}$ \\
\hline KS & 70 & 17 & 30 & 24,93 & 3,205 \\
KI & 70 & 17 & 30 & 23,60 & 3,237 \\
KP & 70 & 9 & 20 & 15,56 & 2,619 \\
MB & 70 & 8 & 15 & 11,89 & 1,923 \\
\hline
\end{tabular}

Sumber: Data Diolah (2020)

Berdasarkan Tabel 2 diketahui jika skor untuk nilai tertinggi dan terendah untuk kualitas sistem adalah sebesar 17 dan 30, sedangkan untuk nilai rata-rata kualitas sistem sebesar 24,93 dengan simpangan baku sebesar 3,205. Kualitas informasi memiliki skor dengan nilai tertinggi dan terendah sebesar 17 dan 30, sedangkan untuk nilai rata-ratanya sebesar 23,60 dengan nilai simpangan baku sebesar 3,237. Kepuasan pengguna diketahui memiliki skor untuk nilai 
tertinggi dan terendah sebesar 9 dan 20, sedangkan untuk nilai rata-rata dari kepuasan pengguna yaitu sebesar 15,56 dengan nilai simpangan baku 2,619. Variabel manfaat bersih diketahui memiliki skor untuk nilai tertinggi dan terendah sebesar 8 dan 15, sedangkan untuk nilai rata-ratanya sebesar 11,89 dengan nilai simpangan baku sebesar 1,923. Data yang telah diperoleh dari pengisian kuesioner pada awalnya dilakukan pengujian validitas dan reliabilitas untuk menguji tingkat kevalidan jawaban dan menguji seberapa besar dari hasil jawaban pengisian kuesioner yang dapat dipercaya.

\section{Hasil Uji Validitas, Reliabilitas dan Asumsi Klasik}

Pada penelitian ini telah lolos uji validitas karena seluruh nilai $r$ hitung (pearson correlation) pada setiap kuesioer lebih besar daripada $r$ tabel ( $r$ hitung $>0,2352$ ). Penelitian ini juga telah lolos uji realibilitas karena nilai cronbach's alpha dari seluruh variabel lebih besar daripada 0,6 (cronbach's alpha $>0,6$ ). Langkah selanjutnya, dilakukan uji asumsi klasik pada data yang diperoleh. Data yang diperoleh dalam penelitian ini telah lolos uji asumsi klasik untuk normalitas, heteroskedastisitas, multikolinieritas dan linearitas.

Pada penelitian ini dilakukan sebanyak dua kali uji asumsi klasik dikarenakan dalam penelitian ini terdapat dua variabel terikat. Uji asumsi klasik pertama dilakukan untuk menguji model satu yaitu pengaruh kualitas sistem dan kualitas informasi terhadap kepuasan pengguna. Uji asumsi klasik kedua dilakukan untuk menguji model dua yaitu pengaruh kualitas sistem, kualitas informasi dan kepuasan pengguna terhadap manfaat bersih. Penelitian ini menggunakan uji normalitas Kolmogorov-smirnov yang menghasilkan nilai asyimp sig sebesar 0,200 untuk model satu dan 0,99 untuk model dua yang nilainya lebih besar dari 0,05 sehingga dapat dikatakan penelitian ini telah lolos uji normalitas.

Penelitian ini tidak timbul masalah heteroskedastisitas yang dibuktikan dari nilai sig untuk model satu yaitu KS sebesar 0,983 dan KI sebesar 0,530 yang lebih besar dari 0,05. Pada model juga tidak timbul masalah heteroskedastisitas yang dapat dibuktikan dari nilai sig pada KS sebesar 0,451; KI sebesar 0,177 dan KP sebesar 0,185. Pengujian multikolinearitas dalam penelitian ini yaitu menggunakan nilai VIF (Varians Inflating Factor) jika nilai VIF tidak lebih dari 10 maka dapat dikatakan bahwa penelitian ini tidak memiliki masalah multikolinieritas. Pada penelitian ini baik model satu dan model dua, nilai VIF tidak lebih dari 10 sehingga dalam penelitian ini tidak memiliki masalah multikolinieritas. Pada Pengujian linearitas, baik pada model satu dan model 
dua diketahui masing-masing variabel memiliki hubungan linier yang signifikan antara variabel independent dengan variabel dependent yang dibuktikan dari nilai devation from linearity sig lebih besar dari 0,05.

\section{Hasil Uji Regresi Linier Berganda}

Pada penelitian ini, teknik analisis data yang digunakan adalah regresi linier berganda yang untuk menguji dua model regresi. Model satu yaitu menguji pengaruh antara kualitas sistem dan kualitas informasi terhadap kepuasan pengguna. Sedangkan model dua yaitu untuk menguji pengaruh kualitas sistem, kualitas informasi dan kepuasan pengguna terhadap manfaat bersih. Berikut adalah hasil olah data regresi linier berganda dalam penelitian ini:

\section{Tabel 3. Hasil Pengujian Model 1}

\begin{tabular}{ccccc}
\hline $\begin{array}{c}\text { Variabel } \\
\text { Terikat }\end{array}$ & $\begin{array}{c}\text { Variabel } \\
\text { Bebas }\end{array}$ & Koef. Regresi & Signifikansi & R2 \\
\hline KP & KS & 0,220 & 0,002 & 0,721 \\
& KI & 0,608 & 0,000 & \multirow{2}{*}{}
\end{tabular}

Sumber: Data Diolah (2020)

Berdasarkan dari hasil pengujian pada Tabel 3, menunjukkan jika nilai signifikansi dari KS (Kualitas Sistem) kurang dari nilai alpha yaitu 0,05 (0,002 $<0,05$ ) yang berarti jika KS berpengaruh signifikan terhadap KP (Kepuasan Pengguna). Hasil pengujian juga menunjukkan jika koefisien regresi dari KS bernilai positif yang berarti menunjukkan adanya pengaruh positif KS terhadap KP. Selain itu, pada tabel 3 juga menunjukkan jika nilai signifikansi dari KI (Kualitas Informasi) kurang dari nilai alpha $(0,000<0,05)$ yang berarti jika KI berpengaruh signifikan terhadap KP. Nilai koefisien regresi dari KI juga bernilai positif yang berarti adanya pengaruh positif KI terhadap KP.

\section{Tabel 4. Hasil Pengujian Model 2}

\begin{tabular}{ccccc}
\hline $\begin{array}{c}\text { Variabel } \\
\text { Terikat }\end{array}$ & $\begin{array}{c}\text { Variabel } \\
\text { Bebas }\end{array}$ & Koef. Regresi & Signifikansi & $\mathrm{R}^{2}$ \\
\hline \multirow{2}{*}{ MB } & KS & 0,015 & 0,771 & \\
& KI & 0,329 & 0,000 & 0,698 \\
& KP & 0,237 & 0,005 & \\
\hline
\end{tabular}

Sumber: Data Diolah (2020)

Pada Tabel 4 menunjukkan hasil pengujian regresi linier berganda dari model 2 antara lain yaitu nilai signifikansi dari KS lebih besar dari nilai alpha $(0,771>$ 0,05) yang berarti jika KS tidak memiliki pengaruh terhadap MB (Manfaat Bersih). Pada Tabel 4 juga menunjukkan hasil lain yaitu nilai signifikansi dari KI dan KP lebih kecil daripada nilai alpha yang telah ditentukan $(0,000<0,05)$ 
dan $(0,005<0,05)$ yang berarti masing-masing dari KI dan KP memiliki pengaruh yang signifikan terhadap MB. Nilai koefisien regresi dari KI dan KP juga menunjukkan nilai positif yang berarti jika adanya pengaruh positif dari masing-masing variabel yaitu KI dan KP terhadap MB.

\section{Pembahasan}

Hipotesis pertama (H1) pada penelitian ini yaitu kualitas sistem berpengaruh positif terhadap manfaat bersih. Namun, hasil penelitian menunjukkan jika kualitas sistem tidak berpengaruh terhadap manfaat bersih yang dibuktikan dari hasil nilai signifikansi yang lebih besar dari 0,05 yaitu 0,771 (sig > 0,05), oleh karena itu $\mathrm{H} 1$ pada penelitian ini ditolak. Hasil ini menunjukkan jika kualitas sistem yang digunakan dalam pembelajaran akuntansi tidak memiliki pengaruh terhadap manfaat bersih yang diterima oleh pengguna. Hal ini didukung pula dari pendapat yang diberikan oleh responden yaitu kualitas sistem yang digunakan seperti kemudahan pengoperasian sistem dan kemudahan akses tidak mempengaruhi kinerja atau manfaat bersih yang didapatkan.

Kinerja atau manfaat bersih tersebut seperti membantu dalam meningkatkan nilai dan membantu mempermudah user terkait dengan pemahaman materi dalam kegiatan pembelajaran dan pendidikan akuntansi. Hasil penelitian ini tidak sejalan dengan Krisdiantoro et al. (2018) yang menyatakan kualitas sistem seperti kemudahan pengoperasian dapat membantu meningkatkan kinerja dan produktivitas dalam pengaplikasiannya pada sistem manajemen pengadaan langsung (SIMPeL). Meskipun indikator-indikator pada variabel kualitas sistem dinilai baik, namun tidak dapat meningkatkan manfaat bersih yang diperoleh oleh user seperti membantu dalam meningkatkan nilai atau pemahaman terkait dengan materi dalam kegiatan pembelajaran dan pendidikan akuntansi. Hasil penelitian ini sejalan dengan penelitian yang dilakukan oleh Widodo, Handayani, dan Saifi (2013) yang menyatakan jika kualitas sistem tidak berpengaruh terhadap kinerja.

Hipotesis kedua (H2) pada penelitian ini yaitu kualitas sistem berpengaruh positif terhadap kepuasan pengguna. Pada penelitian ini menunjukkan jika kualitas sistem berpengaruh positif terhadap kepuasan pengguna yang dibuktikan dari hasil nilai signifikansi 0,002 (sig < 0,05). Hasil analisis menunjukkan jika $\mathrm{H} 2$ pada penelitian ini diterima. Responden juga memberikan pendapat yaitu mereka merasa puas dengan kualitas sistem yang digunakan sekarang (FLearn). Menurut mereka selain mudah untuk diakses dan dioperasikan, sistem yang digunakan sekarang juga cukup efektif dan 
efisien untuk digunakan sebagai media dalam pembelajaran dan pendidikan akuntansi.

Davis (1989) menjelaskan jika kualitas sistem sebagai perceived ease of use yaitu tingkat seberapa mudah sistem informasi tersebut dapat dipahami dan digunakan. Hal ini menunjukkan jika user merasa menggunakan sistem informasi mudah, maka mereka tidak memerlukan waktu dan tenaga lebih untuk menggunakannya sehingga akan timbul rasa puas terhadap sistem informasi tersebut. Hasil ini sejalan dengan penelitian Buana dan Wirawati (2018), Rukmiyati dan Budiartha (2016) dan Ikhyanuddin (2017) yang menguji hubungan antara kualitas sistem dengan kepuasan pengguna dan menghasilkan adanya pengaruh yang signifikan.

Hipotesis ketiga (H3) pada penelitian ini adalah kualitas informasi berpengaruh positif terhadap manfaat bersih. Pada hasil pengujian hipotesis ketiga menunjukkan kualitas informasi memiliki pengaruh positif terhadap manfaat bersih dengan tingkat signifikansi sebesar 0,000 (sig < 0,05). Hasil analisis tersebut menunjukkan jika $\mathrm{H} 3$ diterima. Hal ini menunjukkan adanya peningkatan kualitas pada informasi yang dihasilkan oleh FLearn maka akan mampu meningkatkan kualitas dalam pengambilan keputusan, semakin baik informasi yang dihasilkan maka akan meningkatkan kualitas pengambilan keputusan sehingga dapat menyebabkan peningkatan kinerja individu ataupun organisasi.

Hal tersebut didukung pula oleh alasan yang diberikan responden yang menyebutkan dengan adanya berbagai macam informasi yang tersedia seperti e-book dan modul pembelajaran yang terdapat di dalam FLearn dapat memberi manfaat serta membantu mereka dalam memahami materi terkait pembelajaran akuntansi yang akhirnya dapat membantu mereka dalam meningkatkan output atau kinerja yang mereka hasilkan. Hasil penelitian ini sejalan dengan yang dilakukan oleh Widodo, Handayani, dan Saifi (2013) dan Krisdiantoro et al. (2018) yang menghasilkan adanya pengaruh yang signifikan pada hubungan kualitas informasi terhadap kinerja dan manfaat bersih.

Hipotesis keempat (H4) pada penelitian ini adalah kualitas informasi berpengaruh positif terhadap kepuasan pengguna. Hasil pengujian hipotesis pada penelitian ini menunjukkan bahwa kualitas informasi memiliki pengaruh positif terhadap kepuasan pengguna yang dibuktikan dengan tingkat signifikansi sebesar 0,000 $(\mathrm{sig}<0,05)$ sehingga hasil analisis menunjukkan jika H4 pada penelitian ini diterima. Kualitas informasi merupakan kualitas output yang dihasilkan oleh sistem informasi yang digunakan yaitu berupa informasi. 
Jika user percaya bahwa informasi yang yang dihasilkan itu optimal maka mereka akan merasa puas, sehingga semakin tinggi kualitas informasi yang dihasilkan maka user akan merasa puas ketika menggunakan sistem informasi tersebut karena informasi yang dihasilkan telah optimal dan sesuai dengan kebutuhan user.

Hasil tersebut sejalan dengan pendapat yang diberikan responden yaitu mereka merasa puas terhadap kualitas informasi yang dihasilkan oleh FLearn. Menurut mereka portal FLearn telah menyediakan berbagai macam informasi yang memadai seperti e-book, modul pembelajaran dan hal lainnya yang dapat mereka yang dapat diakses kapanpun dan dimanapun sehingga dapat digunakan untuk menunjang dalam pembelajaran dan pendidikan akuntansi. Hasil penelitian ini sesuai dengan penelitian yang dilakukan oleh Rukmiyati dan Budiartha (2016), Nurhayati et al. (2016) dan Supriatna (2012) yang menguji hubungan pengaruh antara kualitas informasi terhadap kepuasan pengguna dan menghasilkan adanya pengaruh yang signifikan.

Hipotesis kelima (H5) pada penelitian ini adalah kepuasan pengguna berpengaruh positif terhadap manfaat bersih. Hasil pengujian menunjukkan jika kepuasan pengguna memiliki pengaruh positif terhadap manfaat bersih. Tingkat signifikansi yang dihasilkan pada pengujian $\mathrm{H} 5$ yaitu sebesar 0,005 (sig $<0,05$ ) yang berarti H5 pada penelitian ini diterima. Hal ini sejalan dengan alasan yang diberikan oleh responden yaitu mereka merasa puas terhadap portal FLearn yang digunakan sebagai salah satu media dalam pembelajaran dan pendidikan akuntansi. Menurut mereka, selain mudah untuk diakses dan dioperasikan portal FLearn juga menyediakan berbagai macam materi pembelajaran dan sesuai dengan materi yang dosen sampaikan sehingga dapat menunjang pembelajaran akuntansi.

Sistem informasi yang berkualitas tentunya akan memberikan rasa kepuasan penggunanya. Pengguna tentunya akan merasa puas karena sistem informasi yang digunakan telah sesuai dengan harapan dan kebutuhan pengguna. Kepuasan tersebut dapat berpengaruh terhadap manfaat atau kinerja yang dihasilkan dari penggunaan sistem informasi tersebut. Hasil penelitian ini sejalan dengan penelitian yang dilakukan oleh Ikhyanuddin (2017) yang menguji hubungan pengaruh antara kepuasan pengguna terhadap manfaat bersih dari penggunaan sistem informasi keuangan daerah yang memperoleh hasil adanya hubungan yang signifikan antara kepuasan pengguna terhadap manfaat bersih. 
Jika dikaitkan dengan model kesuksesan informasi dari DeLone dan McLean (1992) dan teori TAM dari Davis (1989) sebenarnya portal FLearn dianggap telah memiliki kualitas sistem dan informasi yang baik serta telah diterima keberadaannya oleh user. Namun, menurut para responden meskipun indikator-indikator kualitas sistem yang terdapat pada portal FLearn telah dinilai baik, tetapi tidak berdampak terhadap manfaat bersih yang diterima dan tidak dapat membantu mereka khususnya dalam meningkatkan nilai dan membantu mempermudah terkait dengan pemahaman materi dalam kegiatan pembelajaran dan pendidikan akuntansi.

\section{Simpulan}

Pada penelitian ini dapat memberikan bukti empiris yaitu penggunaan teori TAM dari Davis (1989) dan model kesuksesan sistem informasi dari DeLone dan McLean (1992) pada penggunaan sistem informasi di bidang akuntansi khususnya pada pendidikan akuntansi. Hasil dari penelitian ini juga memberikan bukti empiris yaitu kualitas sistem yang ada pada FLearn tidak berpengaruh pada manfaat bersih yang didapatkan oleh user. Penelitian ini juga membuktikan jika kualitas sistem berpengaruh terhadap kepuasan pengguna, semakin baik kualitas sistem maka user akan semakin puas. Pada penelitian ini juga menunjukkan jika kualitas informasi berpengaruh terhadap manfaat bersih dan kepuasan pengguna. Semakin berkualitas informasi atau output yang dihasilkan maka akan semakin bermanfaat dan akan menimbulkan rasa kepuasan bagi user. Selain itu, pada penelitian ini juga menunjukkan bukti empiris yang lain yaitu kepuasan pengguna berpengaruh terhadap manfaat bersih karena portal FLearn telah sesuai dengan kebutuhan mereka sebagai media penunjang dalam pembelajaran dan pendidikan akuntansi.

Berdasarkan hasil temuan di atas, peningkatan kualitas sistem dan informasi sangat diperlukan. Sehingga, dapat memberikan manfaat yang optimal khususnya terkait dengan pembelajaran dan pendidikan akuntansi. Peningkatan kualitas sistem dan informasi dapat dilakukan dengan cara memperbaiki setiap kekurangan yang ada pada FLearn. Kekurangan yang perlu diperbaiki seperti tidak munculnya notifikasi, terkadang server bermasalah dan error. Selain itu, diharapkan semakin sering dilakukan adanya perawatan terhadap sistem informasi sehingga dapat digunakan dan memberikan manfaat secara optimal.

Penelitian ini memiliki kekurangan dan keterbatasan antara lain jumlah sampel yang dapat dikumpulkan terbilang terbatas, karena adanya pandemi COVID-19 menyebabkan jumlah kuesioner yang direspon oleh responden terbatas. Saran 
untuk penelitian selanjutnya agar dapat memperbanyak jumlah sampel sehingga lebih mempresentasikan hasil yang lebih akurat, serta dapat menambahkan hipotesis dan melakukan uji pada variabel mediasi yaitu pada kepuasan pengguna. Pada penelitian selanjutnya juga dapat menggunakan metode penelitian mixed method. Selain itu, untuk penelitian selanjutnya juga diharapkan agar dilakukan penelitian yang lebih mendalam terkait dengan penggunaan sistem informasi pada bidang akuntansi khususnya pada pendidikan akuntansi.

\section{Daftar Pustaka}

Andoh, C. B. (2018). Predicting students' intention to adopt mobile learning: A combination of theory of reasoned action and technology acceptance model. Journal of Research in Innovative Teaching \& Learning, 11(2), 178-191. https://doi.org/10.1108/JRIT-03-2017-0004

Bakhsh, M., Mahmood, A., \& Sangi, N. A. (2017). Examination of factors influencing students and faculty behavior towards m-learning acceptance: An empirical study. The International Journal of Information and Learning Technology, 34(3), 166-188. https://doi.org/10.1108/IJILT-08-2016-0028

Buana, I. B. G. M. M., \& Wirawati, N. G. P. (2018). Pengaruh kualitas sistem informasi, kualitas informasi, dan perceived usefulness pada kepuasan pengguna sistem informasi akuntansi. E-Jurnal Akuntansi Universitas Udayana, 22(1), 683-713. https://doi.org/10.24843/EJA.2018.v22.i01.p26

Chopra, G., Madan, P., Jaisingh, P., \& Bhaskar, P. (2019). Effectiveness of e-learning portal from students' perspective: A structural equation model (SEM) approach. Interactive Technology and Smart Education, 16(2), 94-116. https://doi.org/10.1108/ITSE-05-2018-0027

Davis, F. (1989). Perceived usefulness, perceived ease of use, and user acceptance of information technology. MIS Quarterly, 13(3), 319-340. https://doi.org/10.2307/249008

Dekeng, S., \& Rahmawati, D. A. (2015). Pengaruh kualitas informasi dan kualitas sistem informasi terhadap kepuasan serta kinerja pengguna sistem informasi. EFEKITIF Jurnal Bisnis Dan Ekonomi, 6(1), 47-59.

DeLone, W. H., \& McLean, E. R. (1992). Information systems success: The quest for the dependent variable. Information Systems Research, 3(1), 60-95.

Effendi, R. (2013). Accounting principles: Prinsip-prinsip akuntansi berbasis SAK ETAP (Edisi Revisi). Jakarta: PT Rajagrafindo.

Fithra, H. (2020). Covid-19 dan pembelajaran daring. Retrieved from Media Indonesia website: $\quad$ https://mediaindonesia.com/read/detail/298964-covid-19-danpembelajaran-daring

Ikhyanuddin. (2017). Faktor-faktor yang mempengaruhi kesuksesan sistem informasi keuangan daerah berbasis akrual di Kabupaten Aceh Besar. Jurnal Ekonomi Manajemen Dan Bisnis, 18(1), 25-50. 
Jaiyeoba, O. O., \& Iloanya, J. (2019). E-learning in tertiary institutions in Botswana: Apathy to adoption. International Journal of Information and Learning Technology, 36(2), 157-168. https://doi.org/10.1108/IJILT-05-2018-0058

Kartikahadi, H. (2016). Akuntansi keuangan berdasarkan SAK berbasis IFRS. Jakarta: Salemba Empat.

Kieso, E, D., Weygandt, J. J., \& Warfield, T. D. (2016). Intermediate accounting (Second). United States: WILEY.

Krisdiantoro, Y., Subekti, I., \& Prihatiningtias, Y. W. (2018). Pengaruh kualitas sistem dan kualitas informasi terhadap manfaat bersih dengan intensitas penggunaan sebagai variabel mediasi. Jurnal Akuntansi Aktual, 5(2), 149-167. https://doi.org/10.17977/um004v5i32019p261

Nurhayati, N., Fauziahdan, U., \& Halimatusadiah, E. (2016). Effect of the of accounting system quality, accounting information and service on user satisfaction in islamic commercial banks in Bandung. International Journal of Multidisciplinary Research and Modern Education, 2(2), 42-48.

Oktavia, D. D. (2016). Faktor-faktor yang mempengaruhi kesuksesan sistem informasi manajemen daerah dengan pendekatan model delone dan mclean yang dimodifikasi. Tesis. Fakultas Ekonomi Dan Bisnis. Universitas Brawijaya.

Organisation for Economic Co-operation and Development. (2018). Programme for international student assesment (PISA) result from PISA 2018.

Pranita, E. (2020). Diumumkan awal maret, ahli: Virus corona masuk Indonesia dari januari. Retrieved from Kompas.com website: https://www.kompas.com/sains/read/2020/05/11/130600623/diumumkanawal-maret-ahli--virus-corona-masuk-indonesia-dari-januari

Rui-Hsin, K., \& Lin, C.-T. (2018). The usage intention of e-learning for police education and training. Policing: An International Journal, 41(1), 98-112. https://doi.org/10.1108/PIJPSM-10-2016-0157

Rukmiyati, N. M. S., \& Budiartha, I. K. (2016). Pengaruh kualitas sistem informasi, kualitas informasi dan perceived usefulness pada kepuasan pengguna akhir software akuntansi (studi empiris pada hotel berbintang di Provinsi Bali). EJurnal Ekonomi Dan Bisnis Universitas Udayana, 5(1), 115-142.

Saleh, T., \& Darwanis, U. B. (2012). Pengaruh kualitas sistem informasi terhadap kualitas informasi akuntansi dalam upaya meningkatkan kepuasan pengguna software akuntansi pada pemerintahan Aceh. Jurnal Akuntansi Pascasarjana Universitas Syiah Kuala, 1(1), 110-124.

Sayekti, F., \& Putarta, P. (2016). Penerapan technology acceptance model (TAM) dalam pengujian model penerimaan sistem informasi keuangan daerah. Jurnal Manajemen Teori Dan Terapan, 9(3), 196-209. https://doi.org/10.20473/jmtt.v9i3.3075

Supriatna, I. (2012). Pengaruh kualitas sistem informasi dan kualitas infromasi terhadap persepsi kegunaan dan kepuasan pengguna. Jurnal Ekonomi, Keuangan, Perbankan Dan Akuntansi, 4(1), 45-60.

Urbach, N., Smolnik, S., \& Riempp, G. (2010). An empirical investigation of employee 
portal success. Journal of Strategic Information Systems, 19(3), 184-206. https://doi.org/10.1016/j.jsis.2010.06.002

Venkatesh, V., \& Davis, F. D. (2000). A theoretical extension of the technology acceptance model: Four longitudinal field studies. Management Science, 46(2), 186-204.

Wahyuni, T. (2011). Uji empiris model delone and mclean terhadap kesuksesan Sistem Informasi Manajemen Daerah (SIMDA). Jurnal Badan Pendidikan Dan Pelatihan Keuangan, 2, 3-25.

Warren, C. S. (2014). Accounting Indonesia adaptation. Jakarta: Salemba Empat.

Widodo, T. W., Handayani, S. R., \& Saifi, M. (2013). Pengaruh aplikasi Sistem Informasi Manajemen (SIM) terhadap kinerja karyawan (Studi kasus pada usaha kecil menengah bidang usaha warnet di Kota Malang). Jurnal Administrasi Bisnis, 7(1), $87-100$

Xinli, H. (2015). Effectiveness of information technology in reducing corruption in China. Electronic Library, 33(1), 52-64. https://doi.org/10.1108/EL-11-20120148 